\title{
Production and Receptions of a Classic
}

Production et réceptions d'un classique

Producción y recepciones de un clásico

\section{Claire Ducournau and Karim Hammou}

Translator. Jasmin Smith and Delaina Haslam

\section{(2) OpenEdition}

\section{Journals}

Electronic version

URL: http://journals.openedition.org/bssg/125

DOI: $10.4000 /$ bssg. 125

ISSN: 2490-9424

\section{Publisher}

Presses universitaires de Vincennes

\section{Electronic reference}

Claire Ducournau and Karim Hammou, "Production and Receptions of a Classic", Biens Symboliques / Symbolic Goods [Online], 1 | 2017, Online since 15 October 2017, connection on 04 March 2021. URL: http://journals.openedition.org/bssg/125 ; DOI: https://doi.org/10.4000/bssg. 125 

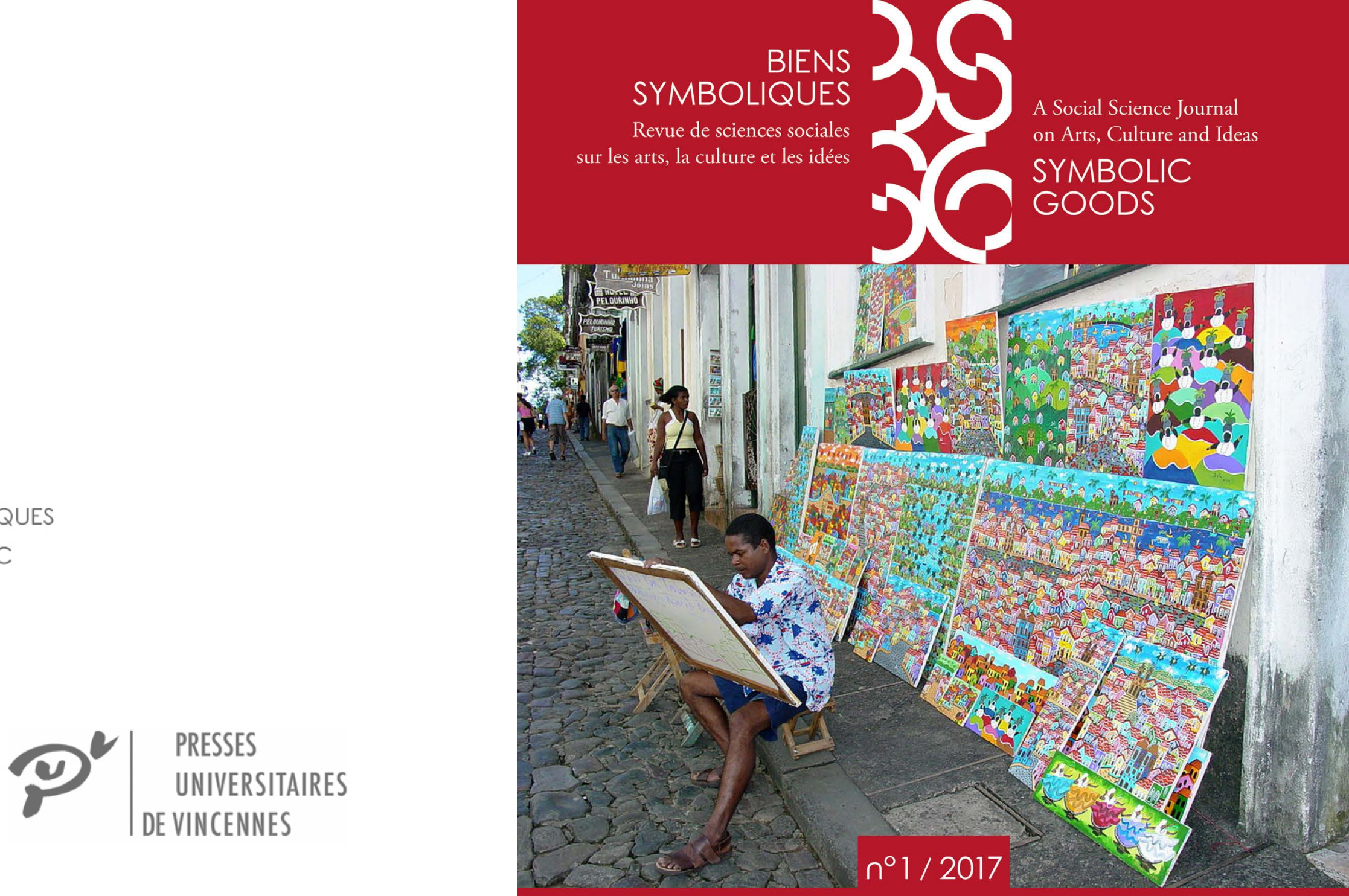

\section{Artistes ordinaires \\ Ordinary Artists}




\title{
Production et réceptions d'un Production and Receptions of a classique Classic
}

\author{
Claire Ducournau | Karim Hammou \\ traduction | translation \\ Jasmin Smith \\ revue par | revised by \\ Delaina Haslam
}

Si la sociologie de la culture a contribué à nourrir les débats théoriques plus généraux qui animent les sciences sociales françaises depuis les années 1960, c'est largement par la médiation d'une poignée de textes aujourd'hui considérés comme des classiques. Le Savant et le Populaire. Misérabilisme et populisme en sociologie et en littérature de Claude Grignon et Jean-Claude Passeron fait partie de ce petit nombre de volumes décisifs, aux côtés de La Culture du pauvre (Hoggart 1970a) et de La Distinction (Bourdieu 1979) par exemple. Ce titre a néanmoins peu circulé à l'international à la différence de ces deux derniers. En donnant la parole à des chercheur.e.s varié.e.s, la table-ronde proposée dans ce premier numéro de Biens Symboliques ${ }^{1}$ voudrait éclairer ce statut paradoxal, en même temps que les héritages du Savant et le Populaire. Dans cette perspective, cette introduction retrace la genèse du livre, on présente quelques-uns de ses apports, en suggère certaines limites, pour réfléchir enfin aux caractéristiques de sa réception.

1 Ce dossier a été coordonné avec l'aide d'Isabelle Gouarné et de Romain Pudal.
While the sociology of culture has helped fuel more general theoretical debate that has enlivened French social science since the 1960s, this has largely been via the mediation of a handful of texts that are considered to be classics today. Le Savant et le Populaire, Misérablisme et populisme en sociologie et en litterature by Claude Grignon and JeanClaude Passeron is one of these few key volumes, together with The Uses of Literacy: Aspects of Working Class Life (Hoggart 1957) and Distinction (Bourdieu 1984). However, unlike the latter two, this title has not enjoyed wide international distribution. By inviting contributions from various researchers, the roundtable proposed in this first issue of Symbolic Goods ${ }^{1}$ seeks to illuminate this paradoxical situation, as well as this work's legacies. From this perspective, the first section of the introduction will retrace the genesis of the book, present some of its strong points, and reference some of its limitations, to better reflect upon the characteristics of its reception in the second section.

1 This project has been coordinated with the collaboration of Isabelle Gouarné and Romain Pudal. 


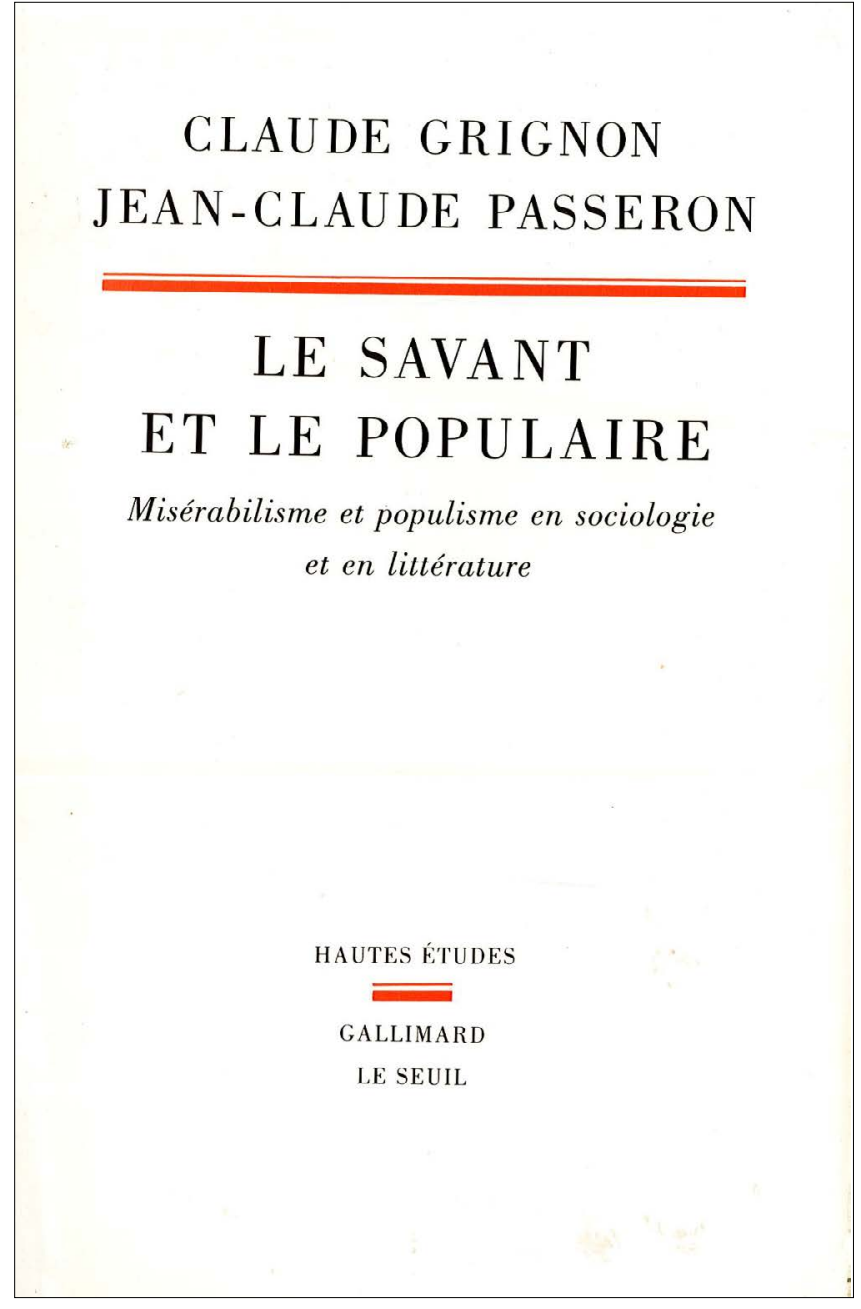

Le Savant et le Populaire, édition de 1989 | 1989 edition c C Gallimard/Le Seuil, « Hautes études ».

LE SAVANT

TE LOPULAIRE

et en littérature

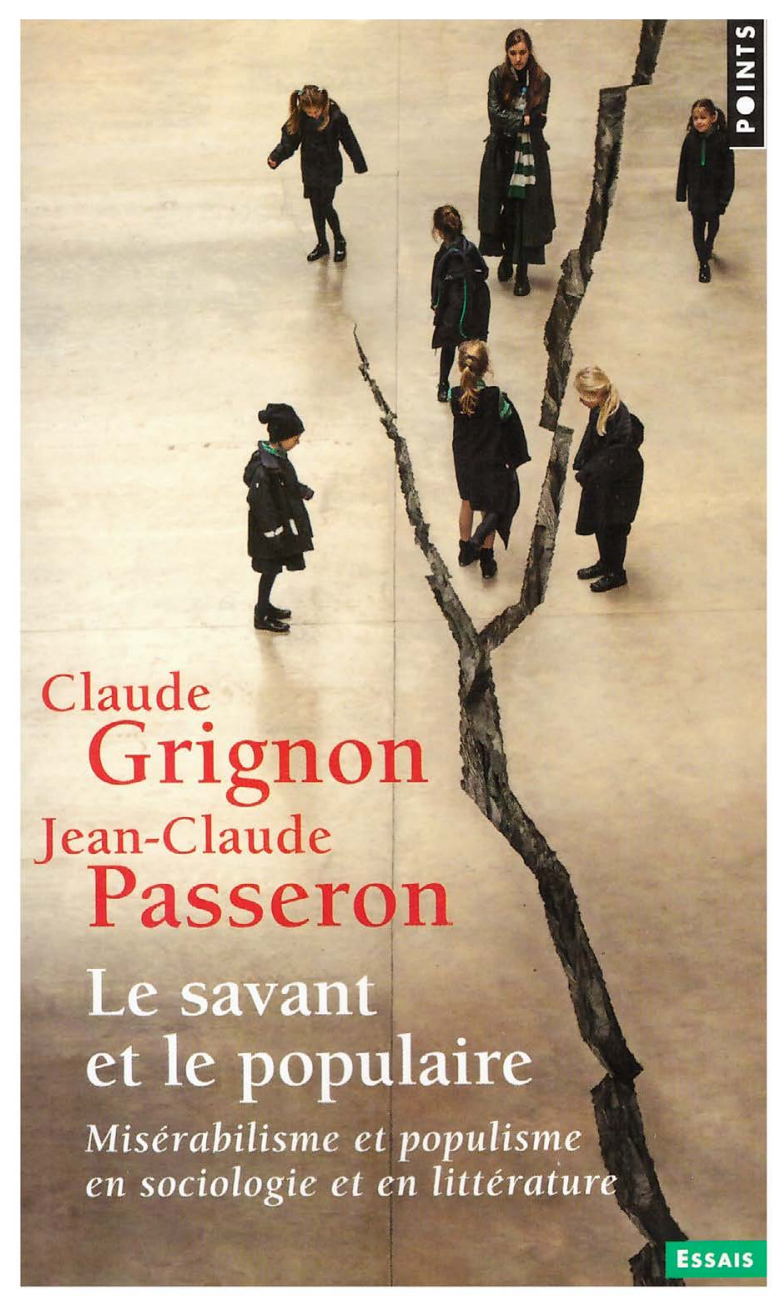

Le Savant et le Populaire, édition de 2015 | 2015 edition (c) Éditions du Seuil, "Points". 


\section{Du séminaire au livre de poche}

Publié en 1989 par les éditions de l'École des hautes études en sciences sociales (EHESS) dans la prestigieuse collection « Hautes études " coéditée par Gallimard et Le Seuil, le texte du Savant et le Populaire retranscrit, sous une forme à peine modifiée, les débats oraux de trois séances d'un séminaire animé par Claude Grignon et Jean-Claude Passeron à l'EHESS sept ans auparavant. En cette année 1982, l'élection de Pierre Bourdieu à la chaire de sociologie du Collège de France coïncide avec le départ officiel de Claude Grignon et de Jean-Claude Chamboredon du Centre de sociologie de l'éducation et de la culture, dont s'était déjà éloigné Jean-Claude Passeron. L'échange qui deviendra Le Savant et le Populaire avait d'abord paru sous une forme plus artisanale comme document ronéotypé du Groupe inter-universitaire de documentation et d'enquêtes sociologiques (Gides), avec le soutien de l'Institut national de la recherche agronomique (INRA) et du Laboratoire d'études et de recherches sociologiques sur la classe ouvrière (Lersco) puis, en 1985, comme premier numéro de la revue Enquête, publiée à Marseille par le Centre d'enquêtes et de recherches sur la culture, la communication, les modes de vie et la socialisation (Cercom). Lucien Malson et Paul Veyne, qui avouait s'être trompé en refusant de publier ce texte à la forme déconcertante que lui avait proposé JeanClaude Passeron, en offrirent des recensions enthousiastes dans la presse généraliste nationale ${ }^{2}$. II fut ensuite réimprimé

2 Lucien Malson, «Culture... et cultures populaires », Le Monde, 26 avril 1984 ; Paul Veyne, « Doctor Miserabilis et Mister Populo. Quand la sociologie cesse d'être puissante et bête comme du Zola », Le Nouvel Observateur, 19-

\section{From seminar to paperback}

Published in 1989 in the prestigious "Hautes études" collection, co-edited by Gallimard and Le Seuil, the text of Le Savant et le Populaire re-transcribes, in a barely modified form, the oral debates that took place over the course of three seminar meetings led by Claude Grignon and Jean-Claude Passeron at the École des hautes études en sciences sociales (EHESS) seven years prior. In that year, 1982, the appointment of Pierre Bourdieu as chair of sociology of the Collège de France coincided with the official departure of Claude Grignon and Jean-Claude Chamboredon from the Centre de sociologie de l'éducation et de la culture, from which Jean-Claude Passeron had already distanced himself. The exchange that would become Le Savant et le Populaire had first appeared in a more rudimentary form as a mimeographed document by the Groupe inter-universitaire de documentation et d'enquêtes sociologiques (Gides) with the support of the Institut national de la recherche agronomique and the Laboratoire d'études et de recherches sociologiques sur la classe ouvrière (Lersco). Then in 1985 it became the first edition of Enquête, published in Marseille by the Centre d'enquêtes et de recherches sur la culture, la communication, les modes de vie et la socialisation (Cercom). Lucien Malson and Paul Veynethe latter admitting to having made a mistake by refusing to publish this text in the rather baffling form proposed to him by Jean-Claude Passeron-offered enthusiastic reviews in the national press ${ }^{2}$. It was then reprinted several times to meet

2 Lucien Malson, "Culture ... et cultures populaires," Le Monde, 26 April 1984 Paul Veyne, "Doctor Miserabilis et Mister Populo. Quand la sociologie cesse d'être puissante et bête comme du Zola," Le Nouvel Observateur, 19-25 July 
de nombreuses fois pour satisfaire une demande croissante, comme en témoigne Philippe Gaboriau dans ce dossier.

Lors des trois séances de débats consacrées les 17 février, 24 février et 10 mars 1982 aux questions empiriques, théoriques et politiques que posent aux sociologues les recherches sur les cultures populaires, Claude Grignon et Jean-Claude Passeron échangeaient entre eux et avec les participant $\cdot \mathrm{e} \cdot \mathrm{s}$, s'appuyant à l'occasion sur des extraits précis d'ouvrages scientifiques ou littéraires. Cela explique certaines caractéristiques de ce texte marqué par une fausse oralité évoquant le dialogue socratique, et ponctué de quelques interventions de chercheur.e.s telxlexs Rose-Marie Lagrave, contributrice à ce dossier. La carrière éditoriale d'abord heurtée de l'ouvrage, qui doit sa publication au plébiscite des universitaires, est toutefois bien celle d'un long-seller situé au pôle de production restreinte et destiné à un public spécialisé, jusqu'à sa réédition en 2015 en livre de poche dans la collection «Points Seuil ».

C'est en effet dans un contexte de profonde redéfinition des rapports des sciences sociales françaises aux cultures populaires que s'inscrit ce débat, dont l'objectif est de définir une position neuve par rapport à deux ensembles de travaux qui s'étaient développés depuis plusieurs décennies en France autour des classes populaires : une veine ethnologique inspirée par le folklorisme d'un côté, une veine marxiste de l'autre. Or, sans tomber dans le mépris de classe, l'ouvrage

25 juillet 1985. Ces deux recensions furent suivies de celle de l'historienne Arlette Farge : «L'oubli du peuple », Libération, 18 janvier 1990 a growing demand, as Philippe Gaboriau attests to in this roundtable.

The three debate sessions, which took place on 17 and 24 February and 10 March 1982, were dedicated to the empirical, theoretical, and political questions posed by research into popular culture. In this context, Claude Grignon and Jean-Claude Passeron discussed precise extracts from scientific and literary texts both together and with the participants. This explains the at-times false orality of the text, which evokes a Socratic dialogue, and occasional interventions by researchers that add to those of the two main authors of the work, such as those of Rose-Marie Lagrave, a contributor to this roundtable. The editorial trajectory of this work-which owes its publication to the support of academics-after initial fits and starts was nevertheless that of a long-seller at the pole of restricted production, intended for a specialist readership, until its reissue in 2015 as a paperback in the Points Seuil collection.

This debate indeed belongs in a context of profound redefinition of the relations between French social science and popular culture, and strives to define a new position relative to two bodies of work on the working class developed over the course of several decades. On the one hand is an ethnological vein inspired by folklorism, and on the other, a Marxist vein. Yet, without disregarding class, Le Savant et le Populaire rejects the working-class rehabilitation approach which had

1985. These two reviews were followed by historian Arlette Farge's "L'oubl du peuple," Libération, 18 January 1990. 
de Grignon et Passeron refuse la démarche de réhabilitation des cultures populaires qui était sous-jacente, depuis les années 1930, au développement de ces travaux (cités dans l'ouvrage, via les références à Marcel Maget par exemple). À partir des années 1970, le déclin du communisme et les désillusions de toute une génération mobilisée à gauche ou à l'extrême-gauche suscitent des désengagements politiques et un «travail de deuil » (Pudal 1991: 63). Des militants reconvertissent dans des recherches universitaires leur intérêt pour les classes populaires, à l'instar de Robert Linhart, Jacques Rancière, Claude Fossé-Poliak ou Gérard Mauger, dont le témoignage nourrit ce dossier. En formulant un discours clair et inédit sur le rapport savant au populaire, Le Savant et le Populaire vient donc répondre, avec succès, à des interrogations qui se sont alors exacerbées.

\section{Des présupposés aux recommandations}

Par son vocabulaire, ses références (de Blaise Pascal à Max Weber en passant par Karl Marx), sa conception de l'espace social et sa manière d'examiner des problèmes aussi bien méthodologiques qu'épistémologiques, le texte reste empreint de la familiarité de ses rédacteurs avec une approche sociologique désormais associée à Pierre Bourdieu. Or, Claude Grignon et Jean-Claude Passeron ont largement contribué à l'élaboration de ce style, tant à travers les publications cruciales de Jean-Claude Passeron avec Pierre Bourdieu dans les années 1960 et 1970, qu'avec l'aventure collective des Actes de la recherche en sciences sociales dans laquelle Claude Grignon fut particulièrement actif (Singly (de) 1998). De ce point de vue, Le Savant et underpinned the development of these works since the 1930s (cited in the work through references to Marcel Maget, for example). From the 1970s, the decline of Communism and the political disengagement of an entire generation from the left or the extreme left led to political disillusionment and a "grieving process" (Pudal 1991: 63). Activists converted their interest in the working class into academic research in the vein of Robert Linhart, Jacques Rancière, Claude FosséPoliak, and Gérard Mauger, whose account is included in this roundtable. By forming a clear and original discourse on the relationship of intellectuals to the popular, Le Savant et le Populaire provided a successful response to questions which came to a head in the 1970s.

\section{From presuppositions to recommendations}

Through its vocabulary, its references (from Blaise Pascal to Max Weber and Karl Marx), its conception of the social space, and its way of examining methodological as well as epistemological problems, the text bears the hallmarks of its authors' familiarity with a sociological approach now associated with Pierre Bourdieu. As a matter of fact, Claude Grignon and Jean-Claude Passeron have largely coproduced this sociological style, as can be seen in the important publications by Jean-Claude Passeron and Pierre Bourdieu in the 1960s and 1970s, or in the collaborative venture Actes de la recherche en sciences sociales in which Claude Grignon was particularly active (Singly (de) 1998). From this point of view, Le Savant et le Populaire constitutes an internal critique 
le Populaire constitue une critique interne d'une théorie sociologique de la « légitimité culturelle » qui s'est forgée au fil de collaborations, avant de se systématiser notamment dans La Distinction (Bourdieu 1979). La virtuosité dans l'usage d'une théorie et d'un style dont les auteurs sont les co-producteurs n'est du reste pas sans effets paradoxaux. Elle conduit parfois à clore des discussions introduites par le public du séminaire sans examen précis de l'objection ou de la référence convoquée. La correspondance ouvrière, présentée comme «pratique ordinaire » par Rose-Marie Lagrave à partir des travaux de Jacques Rancière, se voit ainsi requalifiée comme exceptionnelle par Passeron : «Étaitelle ordinaire ? Ne l'était-elle pas ? On pourrait en discuter. Tous comptes faits, je ne crois pas " (Grignon \& Passeron 2015 : 139). Le Savant et le Populaire offre bien une critique acérée mais " réformiste », comme le suggère Emmanuel Pedler dans ce dossier, de la théorie de la légitimité culturelle et de la description réductrice qu'elle peut livrer des cultures populaires. Ce reproche est du reste porté de façon beaucoup plus radicale par un sociologue comme Patrick Cingolani ou par un philosophe comme le même Rancière à cette époque (collectif Révoltes logiques 1984).

Dans un contexte où il s'agit toujours d'asseoir l'épistémologie de la sociologie, qui n'existe comme cursus universitaire à part entière que depuis deux décennies (Chapoulie 1991), Le Savant et le Populaire enjoint à une créativité méthodologique, à une vigilance interprétative, et à un retour au travail empirique comme garde-fous d'un discours scientifique menacé de tourner à vide. Les métaphores mécaniques y servent ainsi à discréditer les excès interprétatifs : l'« étau of a sociological theory of "cultural legitimacy" which was forged by means of collaborations, before being systemized, notably in Distinction (Bourdieu 1984). The authors' virtuosity in their use of a theory and vocabulary that come naturally to them is certainly not without its paradoxical effects. It sometimes leads, especially when the discussion includes positions that they discredit, to the end of all discussion without any empirical evidence. We thus see working-class correspondence, presented as "ordinary practice" by RoseMarie Lagrave through the work of Jacques Rancière, recharacterized as "exceptional practice" by Passeron: "Was it ordinary? Was it not? We could discuss this. On balance, I don't think it was" (Grignon \& Passeron 2015: 139). Le Savant et le Populaire thus offers a sharp but "reformist" critique, as Emmanuel Pedler suggests in this roundtable, of the theory of cultural legitimacy and its sometimes reductive portrait of popular culture. The reproach is pursued in a much more radical fashion in sociology by Patrick Cingolani, for example, or in philosophy by Jacques Rancière (Collectif Révoltes logiques 1984)

In acontext in which itisstill necessary to establish epistemology of sociology as a discipline-one which has only existed as an autonomous academic discipline for the past two decades - Le Savant et le Populaire promotes a methodological creativity, an interpretive vigilance, and a return to empirical work as the safeguard of a scientific discourse which risks spinning its wheels. Grignon and Passeron show from the opening lines the negative objective of "this debate," which "does not seek 
de la nécessité » qui ferait disparaître le « jeu », la « réponse mécanique à un système de contraintes », " la robotisation intégrale des pratiques populaire » $(52,182,197)$. Claude Grignon et Jean-Claude Passeron affichent dès les premières lignes l'objectif négatif de «ce débat », qui « ne vise pas à proposer une nouvelle théorie des cultures populaires et pas davantage à prescrire une méthodologie préférentielle » (9). Le texte met au contraire en garde contre les « dérives » et « régressions » possibles, au premier chef celles du misérabilisme et du populisme, ce qui ouvre sur des ambitions théoriques déflationnistes par rapport à celles de Bourdieu. Cette méfiance vis-à-vis d'une théorie unifiée peut contribuer à expliquer certains flous conceptuels, comme ceux qui sont entretenus autour des notions pourtant centrales de pouvoir et de domination symbolique (Cornu 2008 ; Hammou 2008). Si le texte veut mettre au premier plan les actes de recherche et la construction de l'objet, ou révéler les affinités parfois impensées qu'ils entretiennent, il ne précise cependant pas non plus les conditions d'application concrètes de certaines (Grignon \& Passeron 2015 : 64-68).

L'épistémologie proposée dans l'ouvrage n'est cependant pas uniquement négative, comme le souligne Grignon deux ans plus tard. II s'agit aussi de « s'engager aussi complètement que possible dans les deux lectures qu'appellent selon nous les cultures populaires » (Grignon et al. 1991 : 37). Les notions phares y sont en effet aussi celles, plus positives, d'alternance et d'ambivalence entre le postulat d'autonomie («dominomorphisme ») et celui d'hétéronomie (« dominocentrisme ») de ces cultures dominées vis-à-vis des cultures dominantes, « de bon contrôle épistémologique » to propose a new theory of popular culture nor to prescribe a preferred methodology" (9). On the contrary, the text warns against possible "derivations" and "regressions"-first those of miserabilism and populism-thus introducing deflationist conceptual ambitions compared with those of Bourdieu. This suspicion of a unified theory may help to explain certain conceptual ambiguities, like those concerning crucial notions such as "symbolic power" and "domination" (Cornu 2008; Hammou 2008). While the text seeks to foreground the practice of research and the construction of the object, or to reveal the sometimes-overlooked affinities on which both these actions can be based, it does not specify the concrete conditions of application of certain of its recommendations (Grignon \& Passeron 2015: 64-68).

The epistemology proposed in the work is not solely negative, however, as Grignon highlighted two years later. It is also about "committing oneself as fully as possible to the two readings that are required, according to us, in order to study popular culture" (Grignon et al. 1991: 37). The leading notions are effectively also the more positive ones of "good epistemological control" (Grignon \& Passeron 2015: 122 ), of alternance and ambivalence between the premise of autonomy ("dominomorphism") and that of heteronomy ("dominocentrism") of dominated cultures vis-à-vis dominant 
(Grignon \& Passeron 2015 : 122). L'alternance, qui sera davantage privilégiée dans les travaux épistémologiques ultérieurs des deux chercheurs (Passeron 1991), a le mérite d'inciter à retourner à l'exercice empirique (Grignon \& Passeron 2015 : 90-91, 94-95), tout en pointant de façon explicite les limites d'une prétention totalisante du savoir sociologique. Dans un contexte général de diversification des cadres sociologiques d'analyse des faits de culture, ces acquis ouvrent en outre la voie à des recherches d'un nouveau genre, nourries de la (re)lecture de Richard Hoggart ou de Max Weber, qui s'épanouissent notamment dans le centre de recherche créé et dirigé ensuite par Jean-Claude Passeron à l'EHESS-Marseille, comme l'illustrent ici les contributions de Dominique Pasquier et de Philippe Gaboriau.

Rétrospectivement, et à l'aune du programme empirique et théorique proposé par Le Savant et le Populaire, certains points peuvent cependant interroger. Nous en soulignerons

deux.

Tout d'abord, la domination se conjugue dans ces pages au singulier. L'espace social y demeure, au mieux, en deux dimensions. Or, plusieurs illustrations mobilisées à l'appui de la démonstration suggèrent les limites d'une analyse rétive à la prise en compte des rapports sociaux de sexe $(38,142$ - ainsi que la contribution d'Abir Kréfa dans ce dossier), ou de la question du racisme, qui apparaît de façon fugitive (3637). Le Savant et le Populaire affirme ainsi circonscrire sa problématique " aux formes de domination qui s'exercent au sein d'une même société » (18), mais sans inclure dans ce périmètre les configurations coloniales, ni envisager les ones. Alternance, which would be given even greater prominence in the later epistemological works of the two researchers (Passeron 2013 [1991]), has the advantage of encouraging a return to the exercise of empiricism (Grignon \& Passeron 2015: 90-91, 94-95), while explicitly highlighting the limits of sociological knowledge's claim to a totalizing vision. In a general context of diversifying sociological analytical frameworks for facts of culture, these experiences furthermore open the door to new kinds of research, informed by the (re)reading of Richard Hoggart and Max Weber, which flourish notably in the research centre created and directed by Jean-Claude Passeron at EHESS-Marseille, as Dominique Pasquier's and Philippe Gaboriau's contributions illustrate here.

In retrospect, and considering the empirical and theoretical programme proposed by Le Savant et le Populaire, certain points can, however, be examined more closely. We will underline two of them.

First, this book shows only one type of domination. The social space remains, at best, two-dimensional. Yet, several illustrations used for the purposes of demonstration suggest the limits of an analysis that is resistant to consideration of gender relations, for example $(38,142)$. This is also the case for the issue of racism, which appears only fleetingly (36-37). Le Savant et le Populaire thus takes into account the "forms of domination that exist within a given society" (18), without including colonialism, nor considering social relationships of race and ethnicity, as pointed out by both Claude Grignon and Philippe Gaboriau in this roundtable. Thanks to such critiques, 
rapports sociaux de race et d'ethnicité, comme le suggèrent, chacun à leur façon, Claude Grignon et Philippe Gaboriau dans ce dossier. Ces remarques incitent à multiplier les dimensions de l'espace social des dominations, mais aussi à soulever le problème du " nationalisme méthodologique " (Wimmer \& Glick Schiller 2002 ; Sapiro 2013b), parfois renforcé, en France, par les outils de la statistique publique. L'aire pertinente d'analyse des phénomènes sociaux, et notamment des rapports de pouvoir, ne s'arrête en effet pas toujours aux frontières des États-nations. Cela ouvre sur un programme de recherche qui peut paraître colossal, mais qui s'inscrit très précisément dans le sillage de l'« allongement du questionnaire » (Veyne 1971) et de l'exigence empirique que Le Savant et le Populaire propose comme principale porte de sortie aux apories de la raison savante.

Ces remarques trouvent un écho dans une autre interrogation. Le Savant et le Populaire entérine peut-être un peu vite la capacité de la sociologie de la culture à « faire un sort à ce qui se donne à voir comme "important" " à l'aide de « la revendication concurrentielle de la légitimité culturelle» (23-24). Cette analyse, qui met l'accent sur les luttes symboliques entre fractions des groupes dominants, s'appuie sur le postulat que les cultures dominantes ont une large autonomie par rapport aux cultures populaires. Mais quid du postulat inverse ? L'ouvrage minimise ainsi le potentiel de l'étude des cultures populaires à interroger en retour les modes d'analyse des cultures dominantes eux-mêmes. La dépendance entre cultures dominante et dominée n'est pas seulement liée à l'interaction asymétrique avec le groupe opposé, à laquelle s'attache principalement Le Savant et le there is acknowledment of an increase in the dimensions of the social space of domination, and they also raise the issue of "methodological nationalism" (Wimmer \& Glick Schiller 2002; Sapiro 2013b), which is also sometimes reinforced by public statistics in France. The pertinent area for analysing social phenomena, and power relations in particular, is indeed not always limited to the borders of nation states. These statements actually open the way to a new form of research, which may appear enormous, but fits perfectly in the wake of the "expansion of inquiry" (Veyne 1971) and the emphasis on the empirical which Le Savant et le Populaire proposes as the main escape route from the aporias of intellectual reasoning.

These remarks are echoed in another line of inquiry. Le Savant et le Populaire perhaps endorses the sociology of culture's capacity to "get rid of what is considered to be "important" rather too quickly with the help of "competitive revindication of cultural legitimacy" (23-24). This analysis, which emphasizes symbolic struggles between elements of dominant groups, is based on the premise that dominant cultures have greater autonomy than popular cultures. But what of the opposite notion? The book thereby tends to play down the study of popular culture's potential to question the way dominant cultures themselves are studied. The interdependence of dominant and dominated cultures is not only tied to the asymetric interaction with the opposite group, with which Le Savant et le Populaire is principally concerned. It is also tied to the constitutive social relationship which distinguishes 
Populaire. Elle est aussi liée au rapport social constitutif qui les distingue et les définit comme telles (dominante versus dominée). Cette problématique est résumée dans la formule marxienne évoquant des " dominants dominés par leur domination ", souvent citée par Bourdieu sans être explorée en tant que telle (Bourdieu 1984: $81 ; 1989$ : $12 ; 1998$ : 76). Elle affleure également dans la lecture que Passeron fait du Marx de L'Idéologie allemande (28-29). Cette piste ne demeure toutefois qu'un horizon, aperçu avec lucidité tant par Grignon que par Passeron, aiguillonnés par Grumbach (125126), sans être davantage investigué dans ses implications épistémologiques. La faute en revient peut-être au repoussoir du relativisme, rappelé dans ce dossier par Grignon luimême, qui justifie ainsi une sorte de fidélité au positivisme bien tempéré sur lequel ont été fondés des pans décisifs de

la sociologie française contemporaine.

Faute de mener jusqu'au bout l'opération méthodologique consistant à traiter à la fois en relativiste et en légitimiste du lieu du discours savant, la sociologie de la culture court le risque, pour les formes culturelles qui se donnent pour dominantes, d'abandonner la lecture idéologique au profit de la seule lecture culturelle. En tenant pour acquise la croyance indigène en l'autonomie de la culture savante, elle peine à formuler le problème théorique des lieux et des moments où le populaire hante le savant. Or l'étude d'objets comme les médias, dont certains " promeuvent très largement les styles de vie et les produits de la culture populaire » (Pasquier 2005 : 65-66), atteste de l'existence de circulations du bas vers le haut de l'échelle sociale. À côté du travail de distinction entre groupes sociaux proches dans l'espace social, voire entre and defines each culture as such (dominant or dominated). This issue is summarized in the Marxian phrase "dominators dominated by their domination," often cited by Bourdieu without being explored as such (Bourdieu 1993; 1996; 1998: 76). It is also evident in Passeron's reading of Marx's The German Ideology (28-29). But this path remains only a horizon, viewed as clearly by Grignon as by Passeron, who were then spurred on by Grumbach (125-126), but without being investigated further in its epistemological implications. The problem perhaps comes back to the rejection of relativism, recalled in this roundtable by Grignon himself. He thereby justifies a form of loyalty to a tempered positivism on which key aspects of contemporary French sociology have been based.

Since it does not fully carry out the methodological operation to both relativize and legitimize the space of scholarly discourse, sociology of culture runs the risk, for cultural forms that are considered dominant, of crushing a cultural reading beneath an ideological one. By taking for granted the indigenous belief in the autonomy of high culture, it struggles to question theoretically places and moments in which the popular haunts the intellectual. Yet the study of topics such as the media, certain sections of which "widely promote lifestyles and products of popular culture" (Pasquier 2005: 65-66), attests to the actual existence of circulations from the bottom to the top of the social ladder. Alongside the work of distinguishing between groups closest to one another in the social space-even between fractions of the dominant 
fractions mêmes du groupe dominant, il existe aussi des caractéristiques que la culture dominante doit à la condition majoritaire des groupes dominants, autrement dit à leur rapport à des groupes dominés situés loin d'eux dans l'espace social. C'est ce qu'ont notamment démontré, sur des cas empiriques précis, les travaux féministes sur « le syndrome de l'androcentrisme » (Mathieu 1991: 83) ou la mise au jour des contraintes discursives que l'idéologie raciste impose à l'écriture journalistique (Guillaumin 1972), pour ne rien dire des recherches plus récentes sur les masculinités (Connell 1995) ou la blanchité (Morrison 1990 ; Roediger 1991)

\section{Non-circulation transnationale et appropriations hétérogènes d'un ouvrage polyphonique}

Contrairement à deux autres ouvrages devenus des classiques des sciences sociales avec lesquels il dialogue, La Distinction et La Culture du pauvre (Coulangeon \& Duval 2013 : 14-15 ; Pasquali \& Schwarz 2016), Le Savant et le Populaire a relativement peu traversé les frontières. Le nombre de citations de l'ouvrage dans la revue anglophone de sociologie de la culture publiée aux Pays-Bas Poetics de 1989 à 2016 l'atteste : 2 seulement pour ce titre, contre 50 pour La Distinction ${ }^{3}$. Traduit à deux reprises en espagnol,

3 Consultation depuis la page de la revue sur «ScienceDirect » le 27 décembre 2016. Une consultation symétrique du nombre d'occurrences du titre des deux ouvrages dans des revues de sciences sociales françaises de 1989 à 2016 révèle que Le Savant et le Populaire y est proportionnellement plus présent que dans Poetics, bien que La Distinction y demeure une référence plus fréquente. C'est le cas dans $L a$ Revue francais de sociologie (qui cite 7 fois Le Savant et le Populaire et 23 fois La Distinction), Sociétés contemporaines ( 8 contre 29), Genèses (3 contre 10), Sociétés et représentations group itself-there are also characteristics that the dominant culture owes to its own predominant condition, in other words to its relationship to dominated groups situated furthest away from it in the social space. This has been shown by means of specific empirical cases, in particular by feminist works on "androcentric syndrome" (Mathieu 1991: 83), or by the revelation of the discursive constraints that racist ideology imposes on journalistic writing (Guillaumin 1972), to say nothing of the most recent research on masculinities (Connell 1995), or whiteness (Morrison 1990; Roediger 1991).

\section{Transnational non-circulation and heterogenous appropriations of a polyphonic work}

Unlike the two other classic works in social science with which it dialogues-Distinction by Pierre Bourdieu and The Uses of Literacy: Aspects of Working Class Life by Richard Hoggart (Coulangeon \& Duval 2013: 14-15; Pasquali \& Schwarz 2016)-Le Savant et le Populaire has not crossed many borders. The number of citations of the book in Poeticsthe English-speaking social science review published in the Netherlands on culture, the media and the arts-attests to this fact: there are only two citations for this title, compared with fifty for Distinction ${ }^{3}$. Translated twice into Spanish, in

3 Taken from ScienceDirect, 27 December 2016. A symmetric reading of the number of times these two books' titles appear in French social science journals from 1989 to today, reveals that Le Savant et le Populaire is referenced much more frequently in comparison, but with an imbalance in favour of Distinction. This is the case in La Revue français de sociologie ( 7 for Le Savant et le populaire, compared with 23 for Distinction), Sociétés 
en Espagne et en Argentine, peu après sa parution, il n'a en effet jamais été traduit en anglais, devenu la lingua franca des échanges scientifiques internationaux.

Comment expliquer ce destin international contrarié d'un livre qui reste décisif dans les sciences sociales françaises? L'ouvrage se caractérise pourtant par l'importance de certaines références étrangères, plutôt plus poussées que dans $L a$ Distinction, pour poursuivre la comparaison : les travaux de linguistes comme William Labov ou Basil Bernstein, que Claude Grignon a contribué à traduire en français, et surtout ceux de Richard Hoggart, dont les deux auteurs du Savant et le Populaire ont été les importateurs en France. Un facteur qui a pu peser dans cette absence de circulation est la forme et l'ambition déroutantes de l'ouvrage, comme le souligne Philippe Coulangeon dans ce dossier. La tendance ordinaire de la circulation internationales des idées consiste en effet à ne retenir des travaux universitaires que quelques concepts ou idées abstraites, "souvent déconnectés du matériau empirique qui leur donne sens » (Neveu 2008 : 320). La réception des travaux de Pierre Bourdieu en langue anglaise, portée par quelques traducteurs comme Richard Nice, s'est ainsi surtout déployée à travers certains concepts comme celui de capital (Sapiro 2013a : 55 ; Lamont 2013 : 65). Or, si les illustrations empiriques, qui portent par exemple sur l'alimentation et le langage, ne jouent qu'un rôle secondaire dans Le Savant et le Populaire, l'ouvrage invite avant tout à " casser le monolithe que représente le concept de culture

(1 contre 14), L'Année sociologique (1 contre 10). Consultation depuis le site Cairn.info le 4 janvier 2017.
Spain and in Argentina, shortly after its publication, it has never been translated into English, which has become the lingua franca of international scientific exchange.

Why would a book which remains such a key part of French social science have such limited international exposure? The work is nevertheless characterized by the significance of certain foreign references, which are pushed to the forefront more so than in Distinction, to continue with the comparison: the works of linguists such as William Labov and Basil Bernstein, whose texts Claude Grignon helped to translate into French, and above all those of Richard Hoggart, which the two authors of Le Savant et le Populaire introduced to France. One factor that may explain this lack of exposure is the puzzling form and ambition of the work. The usual tendency regarding the international circulation of academic works is indeed for only some concepts or abstract ideas to be retained-concepts or ideas which are "often disconnected from the empirical material that gives them meaning" (Neveu 2008: 320). The reception of the works of Pierre Bourdieu in the English language, made possible by translators such as Richard Nice, has likewise taken place via certain concepts such as that of capital (Sapiro 2013a: 55; Lamont 2013: 65). Yet while empirical illustrations, which concern, for example, eating habits and language, only play a secondary role in $L e$ Savant et le Populaire, the work encourages the "breaking of the monolith represented by the concept of a dominated

contemporaines ( 8 vs 29), Genèses ( 3 vs 10), Sociétés et représentations (1 vs 14), L'Année sociologique (1 vs 10). Taken from Cairn.info, 4 January 2017. 
dominée » (140), mettant précisément en garde contre les « concepts-bulldozers » (49) et les excès de la théorie (83) qui risque toujours de se geler en « doctrine » (12). Cette non-circulation éclaire aussi en retour l'importation des textes de Pierre Bourdieu dans le monde anglo-américain : ils y ont été diffusés sans être accompagnés de plusieurs de leurs critiques internes majeures. Conçue à l'extérieur du contexte français, la critique qu'a apportée Richard Peterson à la théorie de la légitimité culturelle avec le concept d'omnivorité

y a fait en revanche florès (Lamont 2013).

Le Savant et le Populaire s'inscrit en outre de façon oblique dans le débat scientifique international. L'ouvrage porte la marque des débats qui ont agité les sciences sociales françaises des années 1970 : l'histoire des cultures populaires, d'une part, à partir de l'ouvrage que Robert Mandrou (1964) lui consacre pour les $X \mathrm{VII}{ }^{\mathrm{e}}$ et $\mathrm{XVIII}{ }^{\mathrm{e}}$ siècles, le renouvellement théorique et institutionnel de l'après-Mai 1968 d'autre part. Dans les années 1970, le débat entre historien'ne·s autour de la façon d'explorer les cultures populaires est particulièrement vif (Kalifa 2005), et se prolonge dans une discussion internationale (Boutier 2008) à la fin de cette décennie (Ginzburg 1976 ; Burke 1978 ; Schilling 1981). Or Le Savant et le Populaire dialogue peu avec ces travaux, qui débouchent au tournant des années 1990 sur la new cultural history. Parallèlement, une autre rencontre entre sociologie, littérature et histoire se joue à Birmingham, dans un contexte britannique de renouvellement intellectuel et institutionnel qui n'est pas sans faire écho aux expériences interdisciplinaires de I'Université de Vincennes, comme le souligne Derek Robbins dans ce dossier. De l'émergence des Cultural Studies dès les culture" (140), warning against "bulldozing-concepts" (49), and the excesses of theory (83), which always risk becoming frozen in "doctrine" (12). This lack of circulation highlights in turn the importation of Pierre Bourdieu's texts into the AngloAmerican world, where they have been diffused without many of their major internal critiques. Conceived as it was outside the French context, Richard Peterson's critique of the theory of cultural legitimacy with the concept of cultural "omnivorousness," however, flourished on the other side of the Atlantic (Lamont 2013).

Le Savant et le Populaire, furthermore, fits into the international scientific debate in an oblique manner. The book bears the mark of the debates that shook up French social science in the 1970s: with, on the one hand, the history of popular culture, beginning with Robert Mandrou's work on the seventeenth and eighteenth centuries (1964); and the theoretical and institutional renewal which followed May 1968 on the other. The debate between historians on how to explore popular culture was in fact particularly heated (Kalifa 2005), and persisted in international discussion (Boutier 2008) from the mid-1970s (Ginzburg 1976; Burke 1978; Schilling 1981). Yet there is little dialogue in Le Savant et le Populaire with these works which led to the development of "new cultural history" at the beginning of the 1990s. Simultaneously, another encounter between sociology, literature, and history was taking place in Birmingham, in a British context of intellectual and institutional renewal not unlike the interdisciplinary experiments which took place at the University of Vincennes, as Derek Robbins explains. However, Le Savant et le Populaire only references Richard Hoggart's - major - work (Ducournau 2017) from the 
années 1960, Le Savant et le Populaire ne retient cependant que l'œuvre, certes majeure, de Richard Hoggart (Ducournau 2017). Ainsi ce dialogue de l'ouvrage avec l'histoire d'un côté, les études culturelles de l'autre, reste donc sélectif, au risque de cantonner sa portée à une discipline, voire à « un cercle intellectuel » (Boutier 2008) en son sein.

L'ouvrage a enfin mis longtemps à trouver un débouché éditorial en France même. Élaboré trois ans après $L a$ Distinction pour ne se voir publié que dix ans après sous forme de livre, nourri (comme ce dernier ouvrage) par des références théoriques et des recherches renvoyant aux années 1960 et 1970, Le Savant et le Populaire donne peu de prises à une réappropriation dans le contexte scientifique anglo-américain des années 1990. La place y est notamment prise, précisément, par les prolongements des Cultural Studies, qui interrogent des dominations plurielles, de sexe et de race par exemple, et font une large place à la notion de résistance (Hall \& Jefferson 1976 ; Scott 2008) - alors que Grignon et Passeron, par méfiance vis-à-vis du populisme, insistent davantage sur les moments d'oubli ou de suspension de la domination (Pasquier 2005). Les Cultural Studies ont aussi été nourries par une discussion critique avec le marxisme, discussion renouvelée par la référence croissante au concept gramscien d'hégémonie. Ce raffinement conceptuel n'y a cependant pas de réel équivalent sur les plans méthodologique et épistémologique (Neveu 2008 : 322, 327-329), qui demeurent précisément deux dimensions cruciales du Savant et le Populaire. field of Cultural Studies that emerged since the 1960s. Thus this dialogue of the book with history on one hand and Cultural Studies on the other remains selective, and risks confining its scope to one discipline, or even to one "intellectual circle" within this discipline (Boutier 2008).

It is necessary to acknowledge that it finally took a long time for the book to find an editorial outlet, even in France. Even though it was developed three years after Distinction, Le Savant et le Populaire had to wait another ten years to be published in book form. Therefore, being full of theoretical references and research dating back to the 1960s and 1970s (again, like Distinction), Grignon and Passeron's work did not leave much room for appropriation in the AngloAmerican scientific context of the 1990s. In that context, due to the extension of Cultural Studies, questions of multiple domination, of sex or race for example, were addressed and room made for the notion of resistance (Hall \& Jefferson 1976; Scott 1992) - while Grignon and Passeron, careful to avoid populism, insist more on moments in which domination could be forgotten or suspended (Pasquier 2005). Cultural Studies was also fed by a critical discussion with Marxism, which has long contributed to these approaches and is renewed through increasing reference to the Gramscian concept of hegemony. This conceptual refinement is not, however, matched by methodological or epistemological equivalents in Cultural Studies (Neveu 2008: 322, 327-329), whereas methodology and epistemology remain precisely the most important paths opened by Le Savant et le Populaire. 
Comme le révèlent les contributions à ce dossier, il existe différentes manières d'interpréter ce texte polyphonique. Gérard Mauger lit le livre avec Bourdieu, lorsque Dominique Pasquier le lit plutôt contre Bourdieu. À l'inverse d'Emmanuel Pedler, Philippe Gaboriau élève le livre au rang de titre phare de sa bibliothèque idéale. Ce dernier décèle dans le texte des affinités avec les approches de Paul Veyne et de Michel Foucault, alors que Déborah Cohen, qui voit a posteriori dans la notion d'ambivalence le vrai résultat du livre, l'a plutôt lu « contre » Foucault. Si cette hétérogénéité est un résultat courant des enquêtes empiriques de réception, elle peut s'expliquer ici par la liberté que nous avions donnée aux chercheur.e.s sollicité·e.s. Plus généralement, il semble que la réception de l'ouvrage n'ait jamais vraiment stabilisé de vulgate, au-delà de l'injonction à se prémunir du double écueil de l'ethnocentrisme de classe représenté par le misérabilisme et le populisme. Ce résultat peut aussi témoigner de la richesse scientifique de ce texte généreux, comme le formule Christine Détrez, en même temps que de certains de ses points aveugles. Il peut être lu comme un discours homogène ou comme un débat à plusieurs voix dont les protagonistes ne s'accordent pas entre eux, et laissent certaines questions en suspens. Les références des deux sociologues ne sont pas les mêmes - si la lecture de Pascal (Grignon \& Passeron 2015 : 31) et les notions psychanalytiques (120) sont présentes chez Passeron, Michel de Certeau (importé avec succès dans les Cultural Studies outre-Manche) se voit en revanche rejeté par Grignon pour l'« empoétisation » populiste dont il se rendrait coupable (164). Leur rapport à l'interdisciplinarité est également distinct. Cette dernière est rejetée par Grignon en vertu de l'affirmation de la sociologie comme science
As shown through the contributions to this roundtable, there are different ways of interpreting this polyphonic text. Gérard Mauger reads the book in accordance with Bourdieu, while Dominique Pasquier reads it "against" Bourdieu. Unlike Emmanuel Pedler, Philippe Gaboriau raises the title to the rank of an essential book in his ideal library. He even discovers affinities with the approaches of Veyne and Foucault in the text; while Déborah Cohen, who sees a posteriori the notion of ambivalence as its true result, has read the book "against" Foucault, and so on. Although such a heterogeneity is a common result of empirical studies of reception, it can be explained here by the freedom that we have given to the solicited researchers. More generally, it seems that the reception of the book never stabilized beyond the injunction to defend against the double hurdle of class ethnocentrism represented by miserabilism and populism. This result can also testify to both the scientific richness of the text, as shown by Christine Détrez, and its blindspots. It can be read as a homogenous discourse or as a multifaceted debate whose protagonists do not agree amongst themselves, and leave certain questions unanswered. The two sociologists references are not the same-while the reading of Pascal (Grignon \& Passeron 2015: 31) and psychoanalytic notions (120) are presented through Passeron, Michel de Certeau (imported successfully into Cultural Studies across the Channel) is, on the other hand, rejected by Grignon for being guilty of a populist "poetization" (164). Their relation to interdisciplinarity is equally distinct. Grignon being a firm believer in sociology as a science with its own rules (Grignon \& Passeron 2015: 67), tends to reject literary writing, which is then mostly reduced to a romantic illusion of reality. Passeron, 
dotée de ses règles propres (Grignon \& Passeron 2015 : 67 ), ce qui nourrit le rejet de l'écriture littéraire, au prix d'une vision restreinte de cette dernière, principalement assimilée à l'illusion romanesque de la réalité. L'interdisciplinarité se voit davantage défendue par Passeron, qui fait l'éloge de l'indiscipline d'Hoggart (65) et défend ensuite la commune condition épistémologique de l'histoire et de la sociologie

(1991: 8).

À la lumière de cet héritage pluriel, l'ouvrage garde une actualité forte, en particulier par son exigence de mise à l'épreuve empirique et de description fine des tâches concrètes que cette mise à l'épreuve implique, lorsqu'il est question d'articuler rapports de force et rapports de sens.

Claire Ducournau Université Paul-Valéry-Montpellier 3/RIRRA21 http://rirra21.upv.univ-montp3.fr/ Karim Hammou

CNRS-Cresppa-CSU http://www.cresppa.cnrs.fr/csu/

\section{Références bibliographiques}

Aron Raymond (1983). Mémoires. Paris, Julliard.

BAKHTINE Mikhaïl (1970). L'CEuvre de François Rabelais et la culture populaire au Moyen Âge et sous la Renaissance. Paris, Gallimard.

BeCKER Howard (1988). Les Mondes de l'art. Traduit de l'anglais par Jeanne Bouniort. Paris, Flammarion.

Bellavance Guy, Boivin Micheline, SanterRe Lise (dir.) (2000). Démocratisation de la culture ou démocratie culturelle ? Deux logiques d'action publique. Québec, Éditions de l'IQRC. on the other hand, is more favourable to interdisciplinarity, praises Hoggart's indiscipline (65), and goes on to defend history and sociology's common epistemological condition (1991: 8).

Considering this pluralist legacy, the book remains extremely relevant today for its insistence in particular on empirical proof and also on the precise descriptions of concrete tasks that such proof implies when it involves connecting power relations with relations of meaning.

Claire Ducournau vv.univ-montp3.fr/ Karim Hammou

CNRS-Cresppa-CSU http://www.cresppa.cnrs.fr/csu/

\section{References}

ARON Raymond (1990). Memoirs: Fifty Years of Political Reflection. English Translation by George Holoch. New York, Holmes and Meier.

BAKHTIN Mikhail M. (1968) [1965]. Rabelais and His World. English translation by Hélène Iswolsky. Cambridge, MA, MIT Press.

BECKER Howard (1982). Art Worlds. Los Angeles, University of California Press.

Bellavance Guy, Boivin Micheline, Santerre Lise (eds.) (2000). Démocratisation de la culture ou démocratie culturelle? Deux logiques d'action publique. Québec, Éditions de I'IQRC. 
BoIs Géraldine (2008). " Le consentement à la domination littéraire. Degrés et diversité de ses formes chez les écrivains "les moins reconnus" de l'univers littéraire ». Tracés, $14: 55-76$.

Bourdieu Pierre (1979). La Distinction. Critique sociale du jugement. Paris, Minuit.

BouRdieu Pierre (1984). Questions de sociologie. Paris, Minuit.

BOURDIEU Pierre (1988). « Entretien recueilli par Beate Krais ». In BOURDIEU Pierre, Chamboredon Jean-Claude, PAsseron Jean-Claude, Le Métier de sociologue. Préalables épistémologiques. Paris, Éditions de l'EHESS (cinquième édition)

Bourdieu Pierre (1989). La Noblesse d'État. Paris, Minuit.

BOURDIEU Pierre (1993). «Les contradictions de l'héritage ». In Bourdieu Pierre (dir.), La Misère du monde. Paris, Seuil : 711-718.

BOURDIEU Pierre (1998) [1992]. Les Règles de l'art. Genèse et structure du champ littéraire. Paris, Seuil.

\section{Bourdieu Pierre (1998). La Domination masculine. Paris, Seuil.}

BOURDIEU Pierre (2003) [1997]. Méditations pascaliennes. Paris, Seuil.
BoIs Géraldine (2008). "Le consentement à la domination littéraire. Degrés et diversité de ses formes chez les écrivains 'les moins reconnus' de l'univers littéraire." Tracés, 14: 55-76.

BouRdieu Pierre (1984). Distinction: A Social Critique of the Judgement of Taste. English translation by Richard Nice. Cambridge, Mass., Harvard University Press.

BOURDIEU Pierre (1993). Sociology in Question. English Translation by Richard Nice. London, SAGE.

BOURDIEU Pierre (1988). "Entretien recueilli par Beate Krais." In BOURDIEU Pierre, Chamboredon Jean-Claude, PAsseron Jean-Claude, Le Métier de sociologue. Préalables épistémologiques. Paris, Éditions de l'EHESS (fifth issue).

Bourdieu Pierre (1996). The State Nobility: Elite Schools in the Field of Power. English translation by Lauretta C. Clough. Palo Alto, Stanford University Press.

BOURDIEU Pierre (1993). "The Contradictions of Inheritance." In BOURDIEU Pierre (ed.), The Weight of the World: Social Suffering in Contemporary Society. English translation by Priscilla Parkhurst Ferguson and al. Cambridge, Polity : 507-513.

BouRdiEU Pierre (1996). The Rules of Art: Genesis and Strucure of the Literary Field. English translation by Susan Emmanuel. Palo Alto, Stanford University Press.

BouRdieU Pierre (2002). Masculine Domination. English translation by Richard Nice. Palo Alto, Stanford University Press.

Bourdieu Pierre (2000). Pascalian Meditations. English Translation by Richard Nice. Palo Alto, Stanford University Press. 
Bourdieu Pierre, Chamboredon Jean-Claude, PAsseron Jean-Claude (1968). Le Métier de sociologue. Paris, Mouton.

Bourdieu Pierre \& PAsseron Jean-Claude (1964). Les Héritiers. Les étudiants et la culture. Paris, Minuit.

BouRdieu Pierre \& PASSERON Jean-Claude (1970). La Reproduction Éléments pour une théorie du système d'enseignement. Paris, Minuit.

BOURDIEU Pierre \& WACQUANT Loïc (2014). Invitation à la sociologie réflexive. Paris, Seuil.

BOUTIER Jean (2008). "Quelques réflexions rétrospectives sur les histoires de la "culture populaire" ». Journée d'étude "Le Savant et le Populaire, 1989-2008. Retour sur un débat en suspens ». SHADYC, EHESS Marseille (non publié).

BOUVERESSE Jacques (2008). « Le besoin de croyance et le besoin de vérité ». Agone, 38-39:281-306.

BuRKE Peter (1978). Popular Culture in Early Modern Europe. Londres, Temple Smith.

Buscatto Marie (2014). Sociologies du genre. Paris, Armand Colin.

BusıNo Giovanni (2006). « Entretien avec Dominique Schnapper ». Revue européenne des sciences sociales, XLIV(135). [En ligne] http://ress. revues.org/271 [consulté le 12 octobre 2016].

Casanova Pascale (2008) [1999]. La République mondiale des lettres. Paris, Seuil.
Bourdieu Pierre, Chamboredon Jean-Claude, PASSERoN Jean-Claude (1991). The Craft of Sociology: Epistemological Preliminaries. English Translation by Richard Nice. Berlin, Gruyter.

Bourdieu Pierre \& PASSERON Jean-Claude (1977). Reproduction in Education, Society and Culture. English Translation by Richard Nice. Beverly Hills, Sage Publications.

BOURDIEU Pierre \& PASSERON Jean-Claude (1979). The Inheritors: French Students and their Relations to Culture. English Translation by Richard Nice. Chicago, University of Chicago Press.

BOURDIEU Pierre \& WACQUANT LoÏc (2014). Invitation à la sociologie réflexive. Paris, Seuil.

BOUTIER Jean (2008). "Quelques réflexions rétrospectives sur les histoires de la 'culture populaire'." Workshop "Le Savant et le Populaire, 19892008. Retour sur un débat en suspens." SHADYC, EHESS Marseille.

BOUVERESSE Jacques (2008). "Le besoin de croyance et le besoin de vérité." Agone, 38-39: 281-306.

BuRke Peter (1978). Popular Culture in Early Modern Europe. London, Temple Smith.

Buscatto Marie (2014). Sociologies du genre. Paris, Armand Colin.

BusıNo Giovanni (2006). "Entretien avec Dominique Schnapper." Revue européenne des sciences sociales, XLIV(135). [On line] http://ress. revues.org/271 [accessed on 12 october 2016].

Casanova Pascale (2005). The World Republic of Letters. English translation by Malcolm B. DeBevoise. Harvard, Harvard University Press. 
CHAPOULIE Jean-Michel (1991). « La seconde fondation de la sociologie française, les États-Unis et la classe ouvrière ». Revue française de sociologie 32(3) : 321-364.

ChARTIER Roger (2001). «Culture écrite et littérature à l'âge moderne ». Annales. Histoire, Sciences sociales, 56(4) : 783-802.

COHEN Déborah (2010). La Nature du peuple. Les formes de l'imaginaire social (XVIII $/ X X I^{e}$ siècles). Seyssel, Champ Vallon.

COLLECTIF (1988). « Histoire et sciences sociales. Un tournant critique ? ». Annales ESC, 2 : 291-293.

Collectif Révoltes logiques (1984). L'Empire du sociologue. Paris, La Découverte.

Collovald Annie (1988). «Identité(s) stratégiques(s) », Actes de la recherche en sciences sociales, $73: 29-40$.

Connell Raewyn (1995). Masculinities. Cambridge, Polity Press.

CoRnu Tanguy (2008). «L'ambiguïté du concept de domination symbolique dans Le Savant et le Populaire ». Journée d'étude « Le Savant et le Populaire, 1989-2008. Retour sur un débat en suspens ». SHADYC, EHESS Marseille (non publié).

Coulangeon Philippe \& Duval Julien (2013). Trente ans après La Distinction de Pierre Bourdieu. Paris, La Découverte.

Coulangeon, Philippe \& Duval Julien (2013). « Introduction ». In EID. (dir.), Trente ans après La Distinction de Pierre Bourdieu. Paris, La Découverte.

Daudet Alphonse (1868). Le Petit Chose. Paris, Pierre-Jules Hetzel.
ChAPOULIE Jean-Michel (1991). "La seconde fondation de la sociologie française, les États-Unis et la classe ouvrière." Revue française de sociologie 32(3): 321-364

ChARTIER Roger (2001). "Culture écrite et littérature à l'âge moderne." Annales. Histoire, Sciences sociales, 56(4): 783-802.

COHEN Déborah (2010). La Nature du peuple. Les formes de l'imaginaire social (XVIII $/ X X I^{e}$ siècles). Seyssel, Champ Vallon.

Collectif (1988). "Histoire et sciences sociales. Un tournant critique?". Annales ESC, 2: 291-293.

Collectif Révoltes logiques (1984). L'Empire du sociologue. Paris, La Découverte.

Collovald Annie (1988). "Identité(s) stratégiques(s)." Actes de la recherche en sciences sociales, 73: 29-40.

\section{Connell Raewyn (1995). Masculinities. Cambridge, Polity Press.}

Cornu Tanguy (2008). "L'ambiguïté du concept de domination symbolique dans Le Savant et le Populaire." Workshop "Le Savant et le Populaire, 1989-2008. Retour sur un débat en suspens." SHADYC, EHESS Marseille.

Coulangeon Philippe \& Duval Julien (2013). Trente ans après La Distinction de Pierre Bourdieu. Paris, La Découverte.

Coulangeon, Philippe \& Duval Julien (2013). "Introduction." In EID. (eds.), Trente ans après La Distinction de Pierre Bourdieu. Paris, La Découverte.

DAUDET Alphonse (1878). Little Good-For-Nothing. English translation by Mary Neal Sherwood. Boston, Estes and Lauriat. 
Debeauvals Michel (1976). L'Université ouverte: les dossiers de Vincennes. Grenoble, Presses Universitaires de Grenoble.

Dragomir Lucia (2011). "L'Union des écrivains. Un modèle institutionnel et ses limites ». Vingtième siècle, $109:$ 59-70.

Ducournau Claire (2017). " Les deux (ou trois) carrières de Richard Hoggart. De la fondation des cultural studies aux appropriations de la sociologie française ». Revue d'anthropologie des connaissances, 11(3) : 263-282.

DUmont Fabienne \& SofIO Séverine (2007). " Esquisse d'une épistémologie de la théorisation féministe en art ». Cahiers du genre, 43 : 17-43.

DUVAL Julien (2010). "Distinction studies ». Actes de la recherche en sciences sociales, 181-182: 146-156.

ELIAS Norbert (1991). La Société des individus. Traduit de l'allemand par Jeanna Etoré. Paris, Fayard.

FABIANI Jean-Louis (dir.) (2001). Le Goût de l'enquête. Pour Jean-Claude Passeron. Paris, L'Harmattan.

FossÉ-PolıAK Claude (2006). Aux frontières du champ littéraire. Sociologie des écrivains amateurs. Paris, Économica.

Foucault Michel (1973). Moi, Pierre Rivière ayant égorgé ma mère, ma sœur et mon frère... Paris, Gallimard/Julliard.

FouCAuLt Michel (1994). Dits et écrits, t. 1 et 2. Paris, Gallimard.

GaboriAu Philippe (1995). Le Tour de France et le vélo. Histoire sociale d'une épopée contemporaine. Paris, L'Harmattan.
DeBEAUVAIS Michel (1976). L'Université ouverte: les dossiers de Vincennes. Grenoble, Presses Universitaires de Grenoble.

DragomiR Lucia (2011). "L'Union des écrivains. Un modèle institutionnel et ses limites." Vingtième siècle, 109: 59-70.

Ducournau Claire (2017). "Les deux (ou trois) carrières de Richard Hoggart. De la fondation des cultural studies aux appropriations de la sociologie française." Revue d'anthropologie des connaissances, 11(3): 263-282.

DUMONT Fabienne \& SofIo Séverine (2007). "Esquisse d'une épistémologie de la théorisation féministe en art." Cahiers du genre, 43: 17-43.

DUVAL Julien (2010). "Distinction studies." Actes de la recherche en sciences sociales, 181-182: 146-156.

ELIAS Norbert (1991). The Society of Individuals. English Translation by Edmund Jephcott. Oxford, Basil Blackwell.

FABIANI Jean-Louis (ed.) (2001). Le Goût de l'enquête. Pour Jean-Claude Passeron. Paris, L'Harmattan.

FossÉ-PolıAK Claude (2006). Aux frontières du champ littéraire. Sociologie des écrivains amateurs. Paris, Économica.

FouCAULT Michel (1982). Pierre Rivière, having slaughtered my mother, my sister, and my brother... A Case of Parricide in the 19th Century. English Translation by Frank Jellinek. Lincoln, University of Nebraska Press.

Foucault Michel (1994). Dits et écrits, t. 1 et 2. Paris, Gallimard.

Gaboriau Philippe (1995). Le Tour de France et le vélo. Histoire sociale d'une épopée contemporaine. Paris, L'Harmattan. 
GaboriaU Philippe (2003). Les Spectacles sportifs. Grandeurs et décadences. Paris, L'Harmattan.

GinZBURg Carlo (1980) [1976]. Le Fromage et les vers. L'univers d'un meunier du XVI siècle [II formaggio e i vermi. II cosmo di un mugnaio del Cinquecento, Turin, Einaudi]. Traduit de l'italien par Monique Aymard. Paris, Flammarion.

Grenier Jean-Yves, Grignon Claude, Menger Pierre-Michel (dir.) (2001). Le Modèle et le récit. Paris, Maison des Sciences de l'Homme.

Grignon Claude (1996). " Le savant et le lettré, ou l'examen d'une désillusion », Revue européenne des sciences sociales, $103: 81-98$.

Grignon Claude (2001). « La formalisation et les sciences du récit, le cas de la sociologie ». In Grenier Jean-Yves, Grignon Claude, Menger Pierre-Michel (dir.), Le Modèle et le récit. Paris, Maison des Sciences de l'Homme : 7-43.

GriGnon Claude \& Kordon Claude (dir.) (2009). Sciences de l'homme et sciences de la nature, essais d'épistémologie comparée. Paris, Maison des Sciences de l'Homme.

Grignon Claude \& PASseron Jean-Claude (1982). Sociologie de la culture et sociologie des cultures populaires. Paris, Documents du GIDES, 4.

Grignon Claude \& Passeron Jean-Claude (1985). Enquête. Cahiers du CERCOM, 1 («À propos des cultures populaires »). [En ligne] https:// enquete.reveues.org/2 [consulté le 26 juin 2017].

Grignon Claude \& Passeron Jean-Claude (2015) [1989]. Le Savant et le Populaire. Misérabilisme et populisme en sociologie et en littérature. Paris, Seuil, "Points " [1re éd. Gallimard/Seuil, " Hautes études "]. En espagnol : Grignon Claude \& Passeron Jean-Claude (1991). Lo culto y lo popular : miserabilismo y populismo en sociologia y en literatura.
GabORIAU Philippe (2003). Les Spectacles sportifs. Grandeurs et décadences. Paris, L'Harmattan.

GinZBURG Carlo (1980). The Cheese and the Worms: the Cosmos of a Sixteenth-Century Miller. English Translation by Ann Tedeschi et John Tedeschi. Baltimore, Johns Hopkins University Press.

Grenier Jean-Yves, Grignon Claude, Menger Pierre-Michel (eds.) (2001). Le Modèle et le récit. Paris, Maison des Sciences de l'Homme.

GriGnon Claude (1996). "Le savant et le lettré, ou l'examen d'une désillusion," Revue européenne des sciences sociales, 103: 81-98.

GriGnON Claude (2001). "La formalisation et les sciences du récit, le cas de la sociologie." In Grenier Jean-Yves, Grignon Claude, Menger Pierre-Michel (eds.), Le Modèle et le récit. Paris, Maison des Sciences de I'Homme: 7-43.

GriGnon Claude \& Kordon Claude (eds.) (2009). Sciences de l'homme et sciences de la nature. Essais d'épistémologie comparée. Paris, Maison des Sciences de l'Homme.

Grignon Claude \& PASSERON Jean-Claude (1982). Sociologie de la culture et sociologie des cultures populaires. Paris, Documents du GIDES, 4

Grignon Claude \& PAsseron Jean-Claude (1985). Enquête. Cahiers du CERCOM, 1 ("À propos des cultures populaires"). [On line] https:// enquete.reveues.org/2 [accessed on 26 june 2017]

Grignon Claude \& PASSERON Jean-Claude (2015) [1989]. Le Savant et le Populaire. Misérabilisme et populisme en sociologie et en littérature.

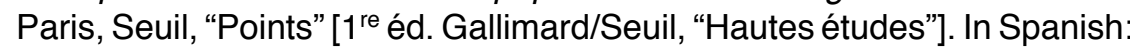
GRIGNON Claude \& PASSERON Jean-Claude (1991). Lo culto y lo popular: miserabilismo y populismo en sociologia y en literatura, Buenos Aires, 
Traduction de María Sonderéguer. Buenos Aires, Ediciones Nueva Vision; Grignon Claude \& Passeron Jean-Claude (1992). Lo culto y lo popular : miserabilismo y populismo en sociologia y en literatura. Traduction de Fernando Alvarez-Uria et Julia Varela. Madrid, Las Ediciones de La Piqueta.

Grignon Claude, Collovald Annie, Pudal Bernard, Sawicki Frédéric (1991). "Un savant et le populaire. Entretien avec Claude Grignon ». Politix, 13 : 35-42.

Gruel Louis (2004). La Rébellion de 68. Une relecture sociologique. Rennes, Presses Universitaires de Rennes.

GUILLAUMIn Colette (2002) [1972]. L'Idéologie raciste. Paris, Gallimard.

Hall Stuart \& JefFerson Tony (dir.) (1976). Resistance through Rituals : Youth Subcultures in Post-War Britain. Londres, Hutchinson.

Hammou Karim (2008). «Penser le pouvoir avec Le Savant et le Populaire ». Journée d'étude "Le Savant et le Populaire, 1989-2008. Retour sur un débat en suspens ». SHADYC, EHESS Marseille (non publié).

HEINICH Nathalie (2000) [1991]. Etre écrivain. Paris, La Découverte.

Hoggart Richard (1970a). La Culture du pauvre. Étude sur le style de vie des classes populaires en Angleterre. Traduit de l'anglais par Françoise Garcia, Jean-Claude Garcia et Jean-Claude Passeron, présentation et index de Jean-Claude Passeron (titre original The Uses of Literacy : Aspects of Working Class Life). Paris, Minuit.

Hoggart Richard (1970b). Speaking to Each Other, vol. 1. Londres, Chatto et Windus.

Hoggart Richard (2013) [1991]. 33 Newport Street. Autobiographie d'un intellectuel issu des classes populaires anglaises. Traduit de l'anglais
Ediciones Nueva Vision. Translated from French to Spanish by María Sonderéguer) ; GriGNON Claude \& PASSERON Jean-Claude (1992). Lo culto y lo popular: miserabilismo y populismo en sociologia y en literatura. Translated from French to Spanish by Fernando Alvarez-Uria y Julia Varela. Madrid, Las Ediciones de La Piqueta.

Grignon Claude, Collovald Annie, Pudal Bernard, Sawicki Frédéric (1991). "Un savant et le populaire. Entretien avec Claude Grignon." Politix, 13: 35-42.

Gruel Louis (2004). La Rébellion de 68. Une relecture sociologique. Rennes, Presses Universitaires de Rennes.

Guillaumin Colette (2002) [1972]. L'Idéologie raciste. Paris, Gallimard.

HaLL Stuart \& JefFERSON Tony (eds.) (1976). Resistance through Rituals: Youth Subcultures in Post-War Britain. London, Hutchinson.

Hammou Karim (2008). "Penser le pouvoir avec Le Savant et le Populaire." Workshop "Le Savant et le Populaire, 1989-2008. Retour sur un débat en suspens." SHADYC, EHESS Marseille.

HeINICH Nathalie (2000) [1991]. Être écrivain. Paris, La Découverte.

HoggaRT Richard (1957). The Uses of Literacy: Aspects of Working Class Life. London, Essential Books.

Hoggart Richard (1970). Speaking to Each Other, vol. 1. London, Chatto et Windus.

Hoggart Richard (1988). A Local Habitation: Life and Times, 1918-1940. London, Chatto \& Windus. 
par Christiane Grignon \& Claude Grignon avec la collaboration de Christopher Todd, présentation de Claude Grignon. Paris, Seuil, « Points » ( $1^{\mathrm{re}}$ éd. Gallimard/Seuil, " Hautes études »).

KaliFA Dominique (2005). "Les historiens français et le "populaire" ». Hermès, $42:$ 54-59.

KRÉFA Abir (2013). " La quête de l'autonomie littéraire en contexte autoritaire : le cas des écrivains tunisiens ». Sociologie, $4: 395-411$.

KRÉFA Abir (2013). Activités littéraires et rapports sociaux de sexe : le cas des écrivains tunisiens (thèse de doctorat en sociologie). Lyon, Université Lyon 2.

KRÉFA Abir (2014). " Entre injonctions à dire et à taire le corps : les voies étroites de la reconnaissance littéraire pour les écrivaines tunisiennes ». Ethnologie française, 44(4) : 631-642.

LAGRAVE Rose-Marie (1980). Le Village romanesque. Le Paradou, Actes Sud, « Espace-temps ».

LAGRAVE Rose-Marie (1988). "Mensonge romanesque et vérité des romanciers. Une relecture du Village Romanesque ». Études Rurales, $109: 55-73$.

LAGRAVE Rose-Marie (2009). " Filiations intellectuelles et espérance sociale. Figure et œuvre de Placide Rambaud ». Études rurales, 183 : 51-66.

Lagrave Rose-Marie (2010). "Se ressaisir ». Genre, Sexualité \& Société, $4: 1$-17. [En ligne] http://gss.revues.org

LAHIRE Bernard (2004). La Culture des individus : dissonances culturelles et distinction de soi. Paris, La Découverte.
KALIFA Dominique (2005). "Les historiens français et le 'populaire'." Hermès, 42: 54-59.

KrÉFA Abir (2013). "La quête de l'autonomie littéraire en contexte autoritaire: le cas des écrivains tunisiens." Sociologie, 4: 395-411.

KRÉFA Abir (2013). Activités littéraires et rapports sociaux de sexe: le cas des écrivains tunisiens (PhD. dissertation, Sociology). Lyon, Université Lyon 2.

KRÉFA Abir (2014). "Entre injonctions à dire et à taire le corps: les voies étroites de la reconnaissance littéraire pour les écrivaines tunisiennes." Ethnologie française, 44(4): 631-642.

LAgraVe Rose-Marie (1980). Le Village romanesque. Le Paradou, Actes Sud, "Espace-temps."

LAGRAVE Rose-Marie (1988). "Mensonge romanesque et vérité des romanciers. Une relecture du Village Romanesque." Études Rurales, 109 : 55-73.

LAGRAVE Rose-Marie (2009). "Filiations intellectuelles et espérance sociale. Figure et œuvre de Placide Rambaud." Études rurales, 183: 51 66

LAGRAVE Rose-Marie (2010). "Se ressaisir." Genre, Sexualité \& Société, 4 : 1-17. [On line] http://gss.revues.org

LAHIRE Bernard (2004). La Culture des individus: dissonances culturelles et distinction de soi. Paris, La Découverte. 
LAHIRE Bernard (2008). La Raison scolaire. École et pratiques d'écriture, entre savoir et pouvoir. Rennes, Presses Universitaires de Rennes.

LahiRe Bernard (2012). Monde pluriel. Penser l'unité des sciences sociales. Paris, La Découverte.

LAMONT Michèle (1995). La Morale et l'argent : les valeurs des cadres en France et aux États-Unis. Paris, Métailié.

LAMONT Michèle (2013). «En quoi Bourdieu a-t-il été utile à notre réflexion ? Le cas des États-Unis ». In CoULANGEON Philippe \& DUVAL Julien (dir.), Trente ans après La Distinction de Pierre Bourdieu. Paris, La Découverte : 59-68.

Levi Giovanni (1989). Le Pouvoir au village. Histoire d'un exorciste dans le Piémont du XVII siècle. Paris, Gallimard.

LINHART Robert (1981). L'Établi. Paris, Minuit.

MACKENZIE Caroline (2012). «Agency, un mot, un engagement 》. Rives méditerranéennes, 41(1). [En ligne] http://rives.revues.org/4139 [consulté le 11 mars 2017].

Mathieu Nicole-Claude (1991). L'Anatomie politique. Paris, Côté-Femmes. MAUGER Gérard (1991). «Enquêter en milieu populaire ». Genèses, 6 : 125-143.

MAUGER Gérard (2005). " Un apprentissage tardif du métier de sociologue ». In MAUGER Gérard (dir.), Rencontres avec Pierre Bourdieu. Bellecombe-en-Bauges, Le Croquant : 239-257.

MAUGER Gérard (2006a). «Sur la violence symbolique ». In MüLLER HansPeter \& Sintomer Yves (dir.). Pierre Bourdieu, théorie et pratique. Paris, La Découverte : 84-100.
LAHIRE Bernard (2008). La Raison scolaire. École et pratiques d'écriture, entre savoir et pouvoir. Rennes, Presses Universitaires de Rennes.

LaHIRE Bernard (2012). Monde pluriel. Penser l'unité des sciences sociales. Paris, La Découverte.

LAMONT Michèle (1994). Money, Morals, and Manners: The Culture of the French and the American Upper-Middle Class. Chicago, University Of Chicago Press.

LAMONT Michèle (2013). "En quoi Bourdieu a-t-il été utile à notre réflexion? Le cas des États-Unis." In CoulANGEON Philippe \& Duval Julien (eds.), Trente ans après La Distinction de Pierre Bourdieu. Paris, La Découverte: 59-68.

LEVI Giovanni (1988). Inheriting Power: The Story of an Exorcist. English translation by Lydia G. Cochrane. Chicago, University of Chicago Press.

LINHART Robert (1981). The Assembly Line. English Translation by Margaret Crosland. Amherst, University of Massachusetts Press.

MACKENZIE Caroline (2012). "Agency, un mot, un engagement." Rives méditerranéennes, 41(1). [On line] http://rives.revues.org/4139 [accessed on 11 march 2017].

MatHIEU Nicole-Claude (1991). L'Anatomie politique. Paris, Côté-Femmes. MAUGER Gérard (1991). "Enquêter en milieu populaire." Genèses, 6: 125143.

MAUGER Gérard (2005). "Un apprentissage tardif du métier de sociologue." In MAUger Gérard (ed.), Rencontres avec Pierre Bourdieu. Bellecombeen-Bauges, Le Croquant: 239-257.

MAUger Gérard (2006a). "Sur la violence symbolique." In MülLeR HansPeter \& Sintomer Yves (eds), Pierre Bourdieu, théorie et pratique. Paris, La Découverte: 84-100. 
MAUGER Gérard (2006b). Les Bandes, le milieu et la bohème populaire. Études de sociologie de la déviance des jeunes des classes populaires (1975-2005). Paris, Belin.

MAUgeR Gérard (2013). " Bourdieu et les classes populaires. L'ambivalence des cultures dominées ». In CoULANGEON Philippe \& DUVAL Julien (dir.), Trente ans après La Distinction de Pierre Bourdieu. Paris, La Découverte : 243-254.

MAUGER Gérard (2014). «Domination ». Le Lexique socius. [En ligne] http:// ressources-socius.info/index.php/lexique/21-lexique/154-domination [consulté le 14 janvier 2017].

MAUGER Gérard \& FossÉ Claude (1977). La Vie buissonnière. Marginalité petite-bourgeoise et marginalité populaire. Paris, Maspero.

MAuger Gérard \& Fossé-Poliak Claude (1985). " Choix politiques et choix de recherches. Essai d'auto-socio-analyse (1973-1984) ». Cahiers « Jeunesses et Sociétés », 3-4-5: 27-121.

Menger Pierre-Michel (2009). Le Travail créateur. S'accomplir dans l'incertain. Paris, Gallimard/Seuil, « Hautes études ».

Morrison Toni (1990). Playing in the Dark : Whiteness and The Literary Imagination. New York, Vintage Books.

MouLin Raymonde (1971). «La Culture du pauvre. À propos du livre de Richard Hoggart ». Revue française de sociologie, 12(2) : 255-258.

MouLIN Raymonde (1992). L'Artiste, l'institution et le marché. Paris, Flammarion.
MAUGER Gérard (2006b). Les Bandes, le milieu et la bohème populaire. Études de sociologie de la déviance des jeunes des classes populaires (1975-2005). Paris, Belin.

MAUGER Gérard (2013). "Bourdieu et les classes populaires. L'ambivalence des cultures dominées." In Coulangeon Philippe \& Duval Julien (eds.), Trente ans après La Distinction de Pierre Bourdieu. Paris, La Découverte: 243-254.

MAUger Gérard (2014). "Domination." Le Lexique socius. [On line] http:// ressources-socius.info/index.php/lexique/21-lexique/154-domination [accessed on 14 january 2017].

MAUger Gérard \& Fossé Claude (1977). La Vie buissonnière. Marginalité petite-bourgeoise et marginalité populaire. Paris, Maspero.

Mauger Gérard \& Fossé-Poliak Claude (1985). "Choix politiques et choix de recherches. Essai d'auto-socio-analyse (1973-1984)." Cahiers "Jeunesses et Sociétés", 3-4-5: 27-121.

Menger Pierre-Michel (2014). The Economics of Creativity: Art and Achievement Under Uncertaint. English Translation by Steven Rendall, Amy Jacobs, Arianne Dorval, Lisette Eskinazi, Emmanuelle Saada, Joe Karaganis. Cambridge (Mass.), Harvard University Press.

Morrison Toni (1990). Playing in the Dark: Whiteness and The Literary Imagination. New York, Vintage Books.

MouLIN Raymonde (1971). "La Culture du pauvre. À propos du livre de Richard Hoggart." Revue française de sociologie, 12(2): 255-258.

Moulin Raymonde (1992). L'Artiste, l'institution et le marché. Paris, Flammarion. 
MouLIN Raymonde (dir.) (1986). Sociologie del'art. Paris, La Documentation française.

Moulin Raymonde, Passeron Jean-Claude, PAsquier Dominique, PortoVASQUEZ Fernando (1985). Les Artistes, essai de morphologie sociale. Paris, La Documentation Française.

NAUDIER Delphine \& Rollet Brigitte (2007). Genre et légitimité culturelle. Quelle reconnaissance pour les femmes?. Paris, L'Harmattan.

Navel Georges (1945). Travaux. Paris, Gallimard.

Neveu Érik (1999). «Pour en finir avec l'enfantisme. Retours sur enquêtes ». Réseaux, 92-93 : 175-201.

NeVEu Érik (2008). « Les voyages des cultural studies ». L'Homme, 187$188: 315-341$.

NoIRIEL Gérard (1988). Le Creuset français. Histoire de l'immigration $\left(X I X^{e}-X X^{e}\right.$ siècle). Paris, Seuil.

OlivieR DE SARDAN Jean-Pierre (2008). La Rigueur du qualitatif. Les contraintes empiriques de l'interprétation socio-anthropologique. Louvain, Bruylant Academia.

Pareto Vilfredo (1917). Traité de sociologie générale. Traduit de l'italien par Pierre Boven. Lausanne, Payot.

Pasqual Paul \& SchwarTz Olivier (2016). « La Culture du pauvre : un classique revisité. Hoggart, Les classes populaires et la mobilité sociale ». Politix, 114 : 21-45.
MouliN Raymonde (ed.) (1986). Sociologie de l'art. Paris, La Documentation française.

Moulin Raymonde, PASSERon Jean-Claude, PAsquier Dominique, PortoVASQUEZ Fernando (1985). Les Artistes, essai de morphologie sociale. Paris, La Documentation Française.

NAUdier Delphine \& Rollet Brigitte (2007). Genre et légitimité culturelle. Quelle reconnaissance pour les femmes?. Paris, L'Harmattan.

Navel George (1949). Man At Work. English translation by George Reavey. London, Dennis Dobson.

NEVEU Érik (1999). "Pour en finir avec l'enfantisme. Retours sur enquêtes." Réseaux, 92-93: 175-201.

Neveu Érik (2008). "Les voyages des cultural studies." L'Homme, 187188: 315-341.

NoIRIEL Gerard (1996). The French Melting Pot: Immigration, Citizenship, and National Identity. English Translation by Geoffroy de Laforcade. Minneapolis, University of Minnesota Press.

Olivier de SARDAN Jean-Pierre (2008). La Rigueur du qualitatif. Les contraintes empiriques de l'interprétation socio-anthropologique. Louvain, Bruylant Academia.

Pareto Vilfredo (1935) [1917]. The Mind and Society: A Treatise on General Sociology. English translation by Andrew Bongiorno and Arthur Livingston. New York, Harcourt, Brace and Company.

Pasquali Paul \& Schwartz Olivier (2016). "La Culture du pauvre: un classique revisité. Hoggart, Les classes populaires et la mobilité sociale." Politix, 114: 21-45. 
Pasqual Paul (2014). Passer les frontières sociales. Comment les «filières d'élite » entrouvrent leurs portes. Paris, Fayard.

PASquiER Dominique (1989). La Culture des sentiments. L'expérience télévisuelle des adolescents. Paris, Éditions de la MSH.

PASQUIER Dominique (2005). « La "culture populaire" à l'épreuve des débats sociologiques ». Hermès, 42 : 60-69.

PASSERON Jean-Claude (2006) [1991]. Le Raisonnement sociologique. Un espace non poppérien de l'argumentation. Paris, Albin Michel, nouvelle édition revue et augmentée (première édition Paris, Nathan).

Passeron Jean-Claude \& Pedler Emmanuel (1991). Le Temps donné aux tableaux. Compte rendu d'une enquête au musée Granet. Marseille, Imerec.

PASSERON Jean-Claude \& GrumBACH Michel (dir.) (1985). L'CEil à la page : enquête sur les images et les bibliothèques. Paris, Bibliothèque publique d'information, Service des études et de la recherche.

PASSERon Jean-Claude (dir.) (1999). Richard Hoggart en France. Paris, Bibliothèque publique d'information.

Pedler Emmanuel (2010). « Les sociologies de la musique de Max Weber et Georg Simmel. Une théorie relationnelle des pratiques musiciennes ». L’Année sociologique, 60(2) : 305-330.

Pedler Emmanuel (2016). L'Esprit des lieux. Paris, Éditions de l'EHESS.

Pedler Emmanuel \& Bourbonnaud David (2002a). « L'offre du festival "in" d'Avignon : effet d'imposition ou stimulation culturelle ? ". Actes du colloque d'Amiens.

Pedler Emmanuel \& Bourbonnaud David (2002b). « La programmation du Festival. Un pacte de confiance entre l'organisation festivalière et son
Pasqual Paul (2014). Passer les frontières sociales. Comment les "filières d'élite" entrouvrent leurs portes. Paris, Fayard.

PASqUIER Dominique (1989). La Culture des sentiments. L'expérience télévisuelle des adolescents. Paris, Éditions de la MSH.

PASQUIER Dominique (2005). "La 'culture populaire' à l'épreuve des débats sociologiques." Hermès, 42: 60-69.

PAsseron Jean-Claude (2013). Sociological Reasoning. A Non-Popperian Space of Argumentatio. English Translation by Rachel Gomme, Edited and Introduced by Professor Derek Robbins. Oxford, Bardwell Press.

PAsseron Jean-Claude \& Pedler Emmanuel (1991). Le Temps donné aux tableaux. Compte rendu d'une enquête au musée Granet. Marseille, Imerec.

PASSERON Jean-Claude \& GRUMBACH Michel (eds.) (1985). L'CEil à la page. enquête sur les images et les bibliothèques. Paris, Bibliothèque publique d'information, Service des études et de la recherche.

PAsseron Jean-Claude (ed.) (1999). Richard Hoggart en France. Paris, Bibliothèque publique d'information.

Pedler Emmanuel (2010). "Les sociologies de la musique de Max Weber et Georg Simmel. Une théorie relationnelle des pratiques musiciennes." L’Année sociologique, 60(2): 305-330.

Pedler Emmanuel (2016). L'Esprit des lieux. Paris, Éditions de l'EHESS.

Pedler Emmanuel \& Bourbonnaud David (2002a). "L'offre du festival 'in' d'Avignon: effet d'imposition ou stimulation culturelle?." Actes du colloque d'Amiens.

Pedler Emmanuel \& Bourbonnaud David (2002b). "La programmation du Festival. Un pacte de confiance entre l'organisation festivalière et son 
public ». In ETHIS Emmanuel (dir.), Avignon : le public réinventé. Paris, La Documentation française : 131-159.

Pedler Emmanuel \& ZerbiB Olivier (2001). Les Nouvelles Technologies à l'épreuve des bibliothèques. Paris, Bibliothèque publique d'information.

Peterson Richard A. \& Simkus Albert (1992). « How Musical Tastes Mark Occupational Status Groups ». In LAMONT Michèle \& FOURNIER Marcel, Cultivating differences : Symbolic Boundaries and the Making of Inequality. Chicago, The University of Chicago Press : 152-168.

Peterson Richard A. (1992). « Understanding audience segmentation : From elite and mass to omnivore and univore ». Poetics, 21(4) : 243-258.

Peterson Richard A. (1997). « The Rise and Fall of Highbrow Snobbery as a Status Marker ». Poetics, 25(2-3) : 75-92.

Peterson Richard A. \& Kenn Roger M. (1996). « Changing Highbrow Taste : from Snob to Omnivore ». American Sociological Review, 61(5) : 900-907.

PudAL Bernard (1991). « Le populaire à l'encan ». Politix, 13 : 53-64.

RANCIÈRE Jacques (1981). La Nuit des prolétaires. Archives du rêve ouvrier. Paris, Fayard.

RANCIÈRE Jacques (2011). La Leçon d'Althusser. Paris, La Fabrique.

ReVEL Jacques (dir.) (1996). Jeux d'échelles. La micro-analyse à l'expérience. Paris, Gallimard/Seuil.

Robinson Eric E. (1968). The New Polytechnics. The People's Universities. Harmondsworth, Penguin. public." In ETHIS Emmanuel (ed.), Avignon: le public réinventé. Paris, La Documentation française: 131-159.

Pedler Emmanuel \& ZerbiB Olivier (2001). Les Nouvelles Technologies à l'épreuve des bibliothèques. Paris, Bibliothèque publique d'information.

Peterson Richard A. \& Simkus Albert (1992). "How Musical Tastes Mark Occupational Status Groups." In LAMONT Michèle \& FOURNIER Marcel, Cultivating differences: Symbolic Boundaries and the Making of Inequality. Chicago, The University of Chicago Press: 152-168.

Peterson Richard A. (1992). "Understanding audience segmentation From elite and mass to omnivore and univore." Poetics, 21(4): 243-258.

Peterson Richard A. (1997). "The Rise and Fall of Highbrow Snobbery as a Status Marker." Poetics, 25(2-3): 75-92.

Peterson Richard A. \& Kern Roger M. (1996). "Changing Highbrow Taste: from Snob to Omnivore." American Sociological Review, 61(5): 900-907.

PudAL Bernard (1991). “Le populaire à l'encan.” Politix, 13: 53-64.

RANCIÈRE Jacques (1989). The Nights of Labor: the Workers' Dream in Nineteenth-Century France. English Translation by John Drury. Philadelphia, Temple University.

RANCIÈRE Jacques (2011). Althusser's Lesson. English Translation by Emiliano Battista. London, Bloomsbury Publishing.

ReVEL Jacques (ed.) (1996). Jeux d'échelles. La micro-analyse à l'expérience. Paris, Gallimard/Seuil.

Robinson Eric E. (1968). The New Polytechnics. The People's Universities. Harmondsworth, Penguin. 
RoEDIGer David (1991). The Wages of Whiteness : Race and the Making of the American Working Class. New York, Verso.

SAPIRO Gisèle (2013a). « La carrière internationale de La Distinction ». In CoulangeON Philippe \& DuvaL Julien (dir.), Trente ans après La Distinction de Pierre Bourdieu. Paris, La Découverte : 45-58.

SAPIRO Gisèle (2013b). « Le champ est-il national ? La théorie de la différenciation sociale au prisme de l'histoire globale ". Actes de la recherche en sciences sociales, $200: 70-85$.

SCHILLING Heinz (1981). Konfessionskonflikt und Staatsbildung. Eine Fallstudie über das Verhältnis von religiösem und sozialem Wandel in der Früh Neuzeit am Beispiel der Grafschaft Lippe. Gütersloh, Bertelsmann.

ScotT James (2008). La Domination et les arts de la résistance. Fragments du discours subalterne. Traduction française par Olivier Ruchet. Paris, Éditions Amsterdam.

Servien Pius (1935). Principes d'esthétique. Problèmes d'art et langage des sciences. Paris, Boivin.

SINGLY François (DE) (1998). "Bourdieu : nom propre d'une entreprise collective ». Le Magazine littéraire, 369 : 39-44.

SUtTon-Smith Brian (1970). «Psychology of Childlore : The Triviality Barrier ». Western Folklore, 29(1) : 1-8.

TAINE Hyppolite (1858). Essais de critique et d'histoire. Paris, Hachette. VeYNe Paul (1971). Comment on écrit l'histoire. Essai d'épistémologie. Paris, Seuil.

VEYNE Paul (2008). Foucault. Sa pensée, sa personne. Paris, Albin Michel.
RoEdIGER David (1991). The Wages of Whiteness: Race and the Making of the American Working Class. New York, Verso.

SAPIRO Gisèle (2013a). "La carrière internationale de La Distinction". In Coulangeon Philippe \& Duval Julien (eds.). Trente ans après La Distinction de Pierre Bourdieu. Paris, La Découverte: 45-58.

SAPIRO Gisèle (2013b). "Le champ est-il national? La théorie de la différenciation sociale au prisme de l'histoire globale." Actes de la recherche en sciences sociales, 200: 70-85.

SCHILLING Heinz (1981). Konfessionskonflikt und Staatsbildung. Eine Fallstudie über das Verhältnis von religiösem und sozialem Wandel in der Früh Neuzeit am Beispiel der Grafschaft Lippe. Gütersloh, Bertelsmann.

ScotT James (1992). Domination and the Arts of Resistance: Hidden Transcripts. Yale, Yale University Press.

Servien Pius (1935). Principes d'esthétique. Problèmes d'art et langage des sciences. Paris, Boivin.

SINGLY François (DE) (1998). "Bourdieu: nom propre d'une entreprise collective." Le Magazine littéraire, 369: 39-44.

SutTon-SMith Brian (1970). "Psychology of Childlore: The Triviality Barrier." Western Folklore, 29(1): 1-8.

TAINE Hyppolite (1858). Essais de critique et d'histoire. Paris, Hachette. VEYNE Paul (1971). Comment on écrit l'histoire. Essai d'épistémologie. Paris, Seuil.

VeYNE Paul (2010). Foucault: His Thought, His Character. English Translation by Janet Lloyd. Cambridge, Polity Press. 
Weber Max (1998) [1921]. Sociologie de la musique. Les fondements rationnels et sociaux de la musique [Die rationalen und soziologischen Grundlagen der Musik, Tübingen, Drei Masken Verlag]. Traduit de l'allemand par Jean Molino et Emmanuel Pedler. Paris, Métailié.

WIMmeR Andreas \& GLICK SCHILLER Nina (2002). « Methodological Nationalism and Beyond : Nation-State Building, Migration and the Social Sciences ». Global Network, 2 : 301-334.
Weber Max (1958) [1921]. The Rational And Social Foundations Of Music. English Translation by Don Martindale, Johannes Riedel, Gertrude Neuwirth. Carbondale, Southern Illionios University Press.

WIMmER Andreas \& GLICK SCHILLER Nina (2002). "Methodologica Nationalism and Beyond: Nation-State Building, Migration and the Social Sciences." Global Network, 2: 301-334. 